JKM (Jurnal Kebidanan Malahayati),Vol 7,No.2.April 2021,

ISSN (Print) 2476-8944 ISSN (Online) 2579-762X, Hal 257-264

\title{
PEMBERIAN BUAH BIT TERHADAP KENAIKAN KADAR HB IBU HAMIL
}

\author{
Panca Nursela ${ }^{1}$, Dwi Marlina Syukri², Devi Kurnisari ${ }^{3}$, Yulistiana Evayanti $^{4}$, Nurul Isnaini ${ }^{*}$ \\ 1,4.5 Prodi DIV Kebidanan Universitas Malahayati \\ 3Prodi DIII Kebidanan Universitas Malahayati \\ ${ }^{2}$ Division of Biological Science,Faculty of Science,Prince of Songkla University, Thailand \\ *Korespondensi email isnaininurul50@yahoo.co.id
}

\section{ABSTRACT GIVING BEETROOT TO INCREASE LEVEL HB OF PREGNANT WOMEN}

Background anemia is a state of decreased levels of hemoglobin, hematocrine and the number of erythrocytes below normal values. Severe anemia if $\mathrm{Hb}<8 \mathrm{gr} / \mathrm{dl}$, mild anemia if $\mathrm{Hb}>8-11 \mathrm{gr} / \mathrm{dl}$ and normal in pregnant women $\mathrm{Hb}>11 \mathrm{gr} / \mathrm{dl}$. Based on the results of the survey conducted by researchers at UPTD Puskesmas Sudimoro Tanggamus Lampung in January-March 2019 there were 54 (100\%) pregnant women who had anemia where 17 (31.4\%) pregnant women had mild anemia.

Purpose of this study is to know the effect of Beetroot juice on hemoglobin levels in pregnant women with anemia in UPTD Puskesmas Sudimoro Tanggamus Lampung.

Methods is a pre-experimental action research with One group pretest - posttest design. There were 54 pregnant women with anemia who were anemic. Sample 17 people, the sampling technique used was purposive sampling. Data collection using observation sheets and data analysis used is the T-dependent test.

Results of the study are known to be the average value of hemoglobin levels before administration of 9,835 beet juice and standard deviation of 0.5689 . The average value of hemoglobin levels after giving beetroot juice is 11,771 and the standard deviation is 1.2164 .

Conclusion There Is The Effect Of Beetroot Juice On Increased Hemoglobin Levels In Pregnant Women With Anemia Pvalue $=0,000<\alpha=0.005$.

Suggestions for pregnant women to consume beet juice regularly to prevent anemia and to consume foods that contain vitamin $\mathrm{C}$.

Keywords: anemia, beetroot, pregnant women

\section{ABSTRAK}

Latar Belakang anemia merupakan suatu keadaan adanya penurunan kadar hemoglobin, hematokrin dan jumlah eritrosit dibawah nilai normal. Anemia berat bila $\mathrm{Hb}<8 \mathrm{gr} / \mathrm{dl}$, anemia ringan jika $\mathrm{Hb}>8-11 \mathrm{gr} / \mathrm{dl}$ dan normal pada ibu hamil $\mathrm{Hb}>11 \mathrm{gr} / \mathrm{dl}$. Berdasarkan hasil prasurvey yang telah peneliti lakukan di UPTD Puskesmas Sudimoro Tanggamus Lampung pada bulan Januari-Maret tahun 2019 terdapat 54 (100\%) ibu hamil yang mengalami anemia dimana $17(31,4 \%)$ ibu hamil mengalami anemia ringan.

Tujuan diketahui Pengaruh Pemberian Jus Buah Bit Terhadap Kadar Hemoglobin lbu Hamil Dengan Anemia Di UPTD Puskesmas Sudimoro Tanggamus Lampung.

Metode tindakan pra eksperimen dengan rancangan One group pretest - posttest design. Seluruh ibu hamil yang anemia di terdapat 54 ibu hamil yang mengalami anemia. Sampel 17 orang, Teknik sampling yang digunakan purposive sampling. Pengumpulan data dengan menggunakan lembar observasi dan analisa data yang digunakan adalah uji T-dependent.

Hasil penelitian diketahui Nilai rata-rata kadar hemoglobin sebelum pemberian Jus buah Bit 9.835 dan standar deviasi 0.5689. Nilai rata-rata kadar hemoglobin sesudah pemberian Jus buah Bit 11.771 dan standar deviasi 1.2164.

Kesimpulan ada Pengaruh pemberian Jus buah Bit Terhadap peningkatan Kadar Hemoglobin Pada Ibu Hamil dengan anemia pvalue $=0,000<\alpha=0,005$.

Saran bagi ibu hamil dapat mengkonsumsi jus buah bit secara rutin guna pencegahan terjadinya anemia serta mengkonsumsi makanan yang mengandung vitamin $\mathrm{C}$.

Kata Kunci: anemia, buah bit, ibu hamil 


\section{PENDAHULUAN}

Anemia merupakan salah satu masalah kesehatan di seluruh dunia terutama Negara berkembang yang diperkirakan $30 \%$ penduduk dunia menderita anemia. Anemia banyak terjadi pada masyarakat terutama pada remaja dan ibu hamil. Anemia pada remaja putri sampai saat ini masih cukup tinggi, menurut WorldHealthOrganization (WHO) (2013), prevalensi anemia dunia berkisar $40-88 \%$. Hasil Riskesdas 2013 menyatakan bahwa anemia terjadi pada $37,1 \%$ ibu hamil di Indonesia, $36,4 \%$ ibu hamil di Perkotaan, dan 37,8\% ibu hamil di Pedesaan (KemenKes RI, 2017).

Menurut Astuti 2018 sekitar 800 perempuan meninggal karena komplikasi kehamilan dan kelahiran anak. Pada proses kelahiran dapat mengakibatkan perdarahan dan akhirnya menyebabkan anemia. Hampir semua kematian ini terjadi karena rendahnya pengaturan sumber daya, dan sebagian besar dapat dicegah. Penyebab utama kematian ibu diantaranya yakni perdarahan, hipertensi, infeksi, dan penyebab tidak langsung. Risiko seorang wanita di negara berkembang meninggal akibat penyebab itu terkait selama hidupnya yakni sekitar 23 kali lebih tinggi dibandingkan dengan wanita yang tinggal di negara maju.

Berdasarkan data Riskesdas 2018, angka anemia ibu hamil sebanyak 48,9\%, anemia berdasarkan umur 15-24 tahun sebanyak $84,6 \%$, 25-34 tahun sebanyak 33,7\%, 35-44 tahun sebanyak $33,6 \%$ dan umur $45-55$ tahun sebanyak $24 \%$. Sedangkan ibu hamil yang mendapat tablet tambah darah sebesar $73,2 \%$ dan yang tidak mendapatkan tablet tambah darah sebesar 26,8\% (Riskesdas, 2018).

Ibu hamil yang mengalami anemia berisiko mengalami keguguran, bayi berat lahir rendah, serta perdarahan sebelum dan saat setelah melahirkan. Pada anemia sedang dan berat, perdarahan dapat menjadi lebih parah sehingga berisiko terhadap terjadinya kematian ibu dan bayi. Dampak terhadap anak yang dilahirkan oleh ibu yang anemia menyebabkan bayi lahir dengan persediaan zat besi yang sangat sedikit di dalam tubuhnya sehingga berisiko mengalami anemia pada usia dini, yang dapat mengakibatkan gangguan atau hambatan peertumbuhan dan perkembangan anak (Susiloningtyas,2021).

Anemia pada kehamilan merupakan salah satu masalah nasional karena mencerminkan nilai kesejahteraan social ekonomi masyarakat dan pengaruhnya sangat besar terhadap kualitas sumber daya manusia. Oleh karena itulah anemia memerlukan perhatian serius dari semua pihak yang terkait dalam pelayanan kesehatan (Desi, 2018). Pengaruh anemia pada saat persalinan yaitu gangguan His, kekuatan mengejan, kala 1 dapat berlangsung lama, kala uri dapat diikuti Retensio Plasenta dan perdarahan post partum karena atonia uteri, kala empat dapat terjadi perdarahan post partum sekunder dan atonia uteri (Manuaba, 2009).

Anemia merupakan salah satu factor penyebab tidak langsung kematian ibu hamil. Angka Kematian Ibu (AKI) di Indonesia adalah tertinggi bila dibandingkan dengan Negara ASEAN lainnya. Perempuan yang meninggal karena komplikasi selama kehamilan dan persalinan mengalami penurunan pada tahun 2013 sebesar 289.000 orang. Target penurunan angka kematian ibu sebesar $75 \%$ antara tahun 1990 dan 2015 (WHO, 2015).

Indonesia memiliki jumlah ibu hamil dengan anemia sebesar $85,17 \%$ dan Provinsi Lampung memiliki jumlah ibu hamil dengan anemia sebesar 69,7\% (KemenKes RI, 2016). Berdasarkan data Dinas Kesehatan Kabupaten Tanggamus, 2018 data anemia ibu hamil di Tanggamus pada tahun 2016 terdapat 253 orang ibu hamil dengan anemia dan mengalami peningkatan pada tahun 2017 sebesar 291 orang ibu hamil dengan anemia, dan prevalensi tertinggi terdapat pada puskesmas Sudimoro sebesar 58 orang $(21,1 \%)$ tahun 2016 sedangkan pada tahun 2017 mengalami kenaikan sebesar 74 orang $(26,3 \%)$ (Dinas Kesehatan Kabupaten Tanggamus, 2017).

Data Survei Demokrasi dan Kesehatan Indonesia (SDKI) pada tahun 2012 menyebutkan bahwa Angka Kematian Ibu (AKI) di Indonesia sebesar 359 per 100.000 kelahiran hidup. Angka tersebut masih jauh dari target RancanganPembangunanJangkaMenengah(RPJM N)tahun2014sebesar 118 per 100.000 kelahiran hidup dan target SustainableDevelpomenGoals (MDG's) sebesar 70 per 100.000 kelahiran hidup. Dimana pnyebab kematian ibu di Indonesia dikarenakan oleh perdarahan sebanyak $30,3 \%$, Hipertensi sebanyak 27,1\%, infeksi sebanyak 7,3\%, partus lama sebanyak $1,8 \%$, abortus sebanyak $1,6 \%$ dan lain-lain sebanyak 40,8\% (Profil Kesehatan Indonesia, 2014). AKI kembali menunjukkan penurunan menjadi 305 per 100.000 kelahiran hiddup berdasarkan hasil Survey Penduduk Antar Sensus (Profil Kesehatan Indonesia, 2017).

Kasus AKI di Lampung terus meningkat, berdasarkan keterangan Dinas Kesehatan Provinsi Lampung pada 2015 terdapat 122 AKI di Lampung. Jumlah itu meningkat menjadi 144 kasus di tahun 


\section{JKM (Jurnal Kebidanan Malahayati),Vol 7,No.2.April 2021, \\ ISSN (Print) 2476-8944 ISSN (Online) 2579-762X, Hal 257-264}

2016 dan tahun 2017 mencapai 158 kasus. Kematian ibu di Provinsi Lampung disebabkan oleh perdarahan sebanyak 47 kasus, eklampsi sebanyak 46 kasus, infeksi sebanyak 9 kasus, partus lama sebanyak 1 kasus, aborsi sebanyak 1 kasus, dan lain-lain sebanyak 54 kasus (Dinas Kesehatan Provinsi Lampung, 2017).

Pada dasarnya anemia disebabkan oleh karena gangguan pembentukan eritrosit oleh sumsum tulang, kehilangan darah keluar dari tubuh (perdarahan) dan proses penghancuran eritrosit dalam tubuh sebelum waktunya (hemolisis). Indonesia masalah anemia pada ibu hamil masih merupakan masalah kesehatan masyarakat karena prevalensinya lebih dari 50\%. (KemenKes Ri, 2016).

Untuk mengatasi anemia pada ibu hamil ada 2 cara penanganan yang dilakukan yaitu secara farmakologi dan non farmakologi. Cara farmakologis yaitu dengan memberikan minimal 90 tablet Fe selama kehamilan yang diharapkan akan meningkatkan kadar $\mathrm{Hb}$ dimana pemberian tablet fe tersebut juga termasuk dalam program pemerintah saat ini. Adapun cara non farmakologis pengobatan anemia dapat dilakukan dengan cara mengkonsumsi buah bit yang kaya antioksidan dan nutrisi, termasuk magnesium, natrium, kalium, Vitamin $\mathrm{C}$, dan betaine, yang berfungsi dengan bertindak pada nutrisi lain untuk mengurangi konsentrasi homosistein, homolog dari alami asam amino sistein, yang telah disarankan untuk dapat merusak pembuluh darah. (Suryandari, 2015).

Keperluan akan zat besi bertambah dalam kehamilan, terutama dalam trimester terakhir. Oleh karena itu ibu hamil harus mengkonsumsi makanan yang kaya zat besi misalnya sayuran berwarna hijau, kacang-kacangan kering, dan buah-buahan kering. Diantara semua buah, Buah bit adalah salah satu buah yang tinggi kadar asam folat yaitu 108 $\mathrm{mg}$ dari buah lainnya. Buah Bit yang dikenal dengana kar bit maupun bit merah ini merupakan salah satu jenis tanaman dari kelompok Amaranthaceace dan memiliki nama latin Beta Vulgaris. Buah Bit mengandung tembaga dan zat besi serta asam folat yang sangat baik untuk membantu pembentukan otak bayi dan mengatasi masalah anemia (Anurogo 2016).

Beberapa penelitian menunjukkan bahwa kandungan senyawa kimia yang terdapat dalam buah bit sangat bermanfaat bagi kesehatan antara lain sebagai pembersih darah yang ampuh, melegakan pernafasan, memaksimalkan perkembangan otak bayi, sebagai anti kanker dan mengatasi anemia. Penelitian ini juga di dukung oleh Suryadari(2014) bahwa mengkonsumsi buah bit (dalam bentuk jus) dapat meningkatkan jumlah leukosit yang lebih tinggi dari pada konsumsi ikan belanak yang dibuktikan dengan perhitungan menggunakan Indepedent Sample Test menghasilkan perbandingan yang bermakna dengan nilai $p=0,000$.

Buah bit memiliki banyak kelebihan bagi kesehatan maupun pengobatan. Kandungan betasianin pada buah bit bermanfaat sebagai anti kanker, karena zat tersebut dapat menghancurkan sel tumor dan kanker. Dalam penelitian Sundari dan Suryawandari (2014) tentang perbandingan kenaikan kadaar $\mathrm{Hb}$ pada ibu hamil yang diberi $\mathrm{Fe}$ dan $\mathrm{Fe}+$ buah bit di wilayah Puskesmas Purwokerto Selatan dengan mengkonsumsi $500 \mathrm{ml}$ selama 7 hari berturut-turut dengan hassil nilai $p=0,009$. Buah bit juga bermanfaat untuk mencegah penyakit stroke, menurunkan kolesterol, mencegah penyakit jantung, memperkuat daya tahan tubuh, mengeluarkan racun dari dalam tubuh, mengobati infeksi dan radang sebagai penghasil energi bagi tubuh serta meningkatkan sistem kekebalan tubuh. Buah bit sangat baik untuk dikonsumsi secara rutin. Kandungan buah bit dalam daftar kandungan bahan makanan antara lain adalah $42 \mathrm{mg}$ kalori, 1,6 gr protein, $0,1 \mathrm{gr}$ lemak, $108 \mathrm{mg}$ asam folat, $27,0 \mathrm{mg}$ kalsium, 43,0 mg fosfor, $43 \mathrm{mg}$ Vitamin C, $23 \mathrm{mg}$ Magnesium, 9,6 mg karbohidrat, dan 1,0 mg zat besi (KemenKes RI, 2016).

Berdasarkan hasil prasurvey yang telah peneliti lakukan di UPTD Puskesmas Sudimoro Tanggamus Lampung pada bulan Januari-Maret tahun 2019 terdapat $54(100 \%)$ ibu hamil yang mengalami anemia dimana $17(31,4 \%)$ ibu hamil mengalami anemia ringan.

\section{METODOLOGI PENELITIAN}

Jenis penelitian ini merupakan penelitian kuantitatif dengan Desain Penelitian yang digunakan adalah Prai Eksperimen dengan pendekatan One Group Pretest Posttest

Populasi dalam penelitian ini adalah seluruh ibu hamil yang mengalami anemia di UPTD Puskesmas Sudimoro Tanggamus Lampung, pada saat dilakukan penelitian yaitu terdapat 54 ibu hamil yang mengalami anemia di UPTD Puskesmas Sudimoro Lampung. Dengan jumlah sampel 17orang. Pengambilan sample penelitian ini dilakukan dengan menggunakan teknik purposve sampling yaitu mengambil sampel berdasarkan kriteria yang peneliti tentukan (Notoatmodjo, 2012). 


\section{HASIL DAN PEMBAHASAN \\ Karakteristik Responden}

Tabel 1.

Karakteristik Responden Berdasarkan Usia, Umur Kehamilan, Pendidikan Dan Paritas

\begin{tabular}{lcc}
\hline \multicolumn{1}{c}{ Variabel } & Jumlah & Frekuensi \\
\hline Usia & & \\
20- 25 Tahun & 8 & $47.1 \%$ \\
26 - 30 tahun & 4 & $23.5 \%$ \\
31 - 35 tahun & 4 & $23.5 \%$ \\
36 - 40 tahun & 1 & $5.9 \%$ \\
Umur Kehamilan & & \\
<20 minggu & 1 & $5.9 \%$ \\
21- 25 minggu & 4 & $23.5 \%$ \\
26-30 minggu & 6 & $35.3 \%$ \\
31-35 minggu & 5 & $29.4 \%$ \\
36- 40 minggu & 1 & $5.9 \%$ \\
Pendidikan & & \\
Rendah (SD, SMP) & 12 & $70.6 \%$ \\
Tinggi (SMA, PT) & 5 & $29.4 \%$ \\
Paritas & & \\
Primipara & 6 & $35.3 \%$ \\
Multipara & 10 & $58.8 \%$ \\
Grandemultipara & 1 & $5.9 \%$ \\
\hline Total & 17 & $100.0 \%$ \\
\hline
\end{tabular}

Berdasarkan tabel 1 dapat diketahui bahwa karakteristik redponden berdasarkan usia 20- 25 tahun sebanyak 8 orang $(47,1 \%)$, usia $26-30$ tahun sebanyak 4 orang $(23,5 \%)$, usia $31-35$ tahun sebanyak 4 orang $(23,5 \%)$ dan $36-40$ tahun sebanyak 1 orang (5,9\%). Karaksteristik respnden berdasarkan umur kehamilan $<20$ minggu sebanyak 1 orang (5,9\%), 21-25 minggu sebanyak 4 orang (23,5\%), 26-30 minggu sebanyak 6 orang $(35,3 \%), 31-35$ minggu sebanyak 5 orang $(29,4 \%)$ dan 36-40 minggu sebanyak 1 orang (5,9\%), karakteristik responden berdasarkan pendidikan rendah sebanyak 12 orang $(70,6 \%)$ dan pendidikan tinggi sebanyak 5 orang $(29,4 \%)$, sedangkan karakteristik berdasarkan paritas primipara 6 orang $(35,3 \%)$, multipara sebanyak 10 orang $(58,8 \%)$ dan grandemultipara sebanyak 1 orang $(5,9 \%)$.

\section{Analisis Univariat \\ Berdasarkan tabel 2 diketahui bahwa nilai rata-rata (mean) Kadar Hemoglobin pada responden sebelum diberikan jus buah bit adalah 9.835 dengan nilai minimal 9.1 dan nilai maksimal 10.1, nilai standar deviasi .5689. Sedangkan nilai rata-rata (mean) Kadar Hemoglobin sesudah diberikan jus buah bit adalah 11.771 dengan nilai minimal 10.1 dan nilai maksimal 14.1, standar deviasi 1.2164.}

Tabel 2.

Kadar Hemoglobin sebelum dan sesudah diberikan Jus buah Bit Terhadap Kadar Hemoglobin Ibu Hamil Dengan Anemia Di UPTD Puskesmas Sudimoro Tanggamus Lampung Tahun 2019

\begin{tabular}{lccccc}
\hline Kadar Hemoglobin & N & Mean & Min & Max & St. Dev \\
\hline Sebelum & 17 & 9.835 & 9.1 & 10.7 & 0.5689 \\
Sesudah & 17 & 11.771 & 10.1 & 14.1 & 1.2164 \\
\hline
\end{tabular}

\section{Analisis Bivariat}

Berdasarkan tabel 3 diketahui bahwa nilai rata-rata (mean) Kadar Hemoglobin pada responden sebelum diberikan jus buah bit adalah 9.835 dengan standar deviasi .5689. Sedangkan nilai rata-rata (mean) Kadar Hemoglobin pada responden sesudah diberikanjus buah bit adalah
11.771 dengan standar deviasi 1.2164 dan selisih rerata 1.9353. Hasil uji statistik dengan uji $t$ dependen sample test diperoleh nilai $p$-value $=$ 0,000 ( $p$-value $<a=0,05$ ), hasil ini menunjukkan bahwa ada Pengaruh pemberian Jus buah Bit Terhadap peningkatan Kadar Hemoglobin Pada Ibu Hamil.

Tabel 3.

Pengaruh Jus buah BitTerhadap Penurunan Kadar Hemoglobin Ibu Hamil Dengan Anemia Di UPTD Puskesmas Sudimoro Tanggamus Lampung Tahun 2019

\begin{tabular}{lcccccc}
\hline Kadar Hemoglobin & $\mathbf{N}$ & Mean & Min-maks & St. Dev & Selisih rerata & p-value \\
\hline Sebelum & \multirow{2}{*}{17} & 9.835 & $9.1-10.7$ & 0.5689 & & \multirow{2}{*}{0,000} \\
Sesudah & & 11.771 & $10.1-14.1$ & 1.2164 & 1.9353 & \\
\hline
\end{tabular}




\section{JKM (Jurnal Kebidanan Malahayati),Vol 7,No.2.April 2021, \\ ISSN (Print) 2476-8944 ISSN (Online) 2579-762X, Hal 257-264}

\section{PEMBAHASAN}

Analisis Univariat

Kadar Hemoglobin Sebelum dan sesudah diberikan Jus buah Bit

Berdasarkan tabel 2 diketahui bahwa nilai rata-rata (mean) Kadar Hemoglobin pada responden sebelum diberikan jus buah bit adalah 9.835 dengan nilai minimal 9.1 dan nilai maksimal 10.1, nilai standar deviasi .5689 . Sedangkan nilai rata-rata (mean) Kadar Hemoglobin sesudah diberikan jus buah bit adalah 11.771 dengan nilai minimal 10.1 dan nilai maksimal 14.1, standar deviasi 1.2164 .

Berdasarkan penelitian Anggraini(2019) yang telah dilakukan di wilayah kerja puskesmas Pekanbaru kota, didapatkan hasil uji statistik dengan menggunakan uji $t$ independent diperoleh $p$ $(0,000)<a(0,05)$. Hal ini dikatakan terdapat perbedaan yang signifikan antara mean kadar hemoglobin ibu hamil dengan anemia pada kelompok eksperimen dan kelompok kontrol sesudah diberikan jus buah bit sehingga dapat disimpulkan bahwa pemberian jus buah bit efektif terhadap kadar hemoglobin ibu hamil dengan anemia.

Penambahan zat besi selama kehamilan kira-kira $1000 \mathrm{mg}$, karena mutlak dibutuhkan untuk janin, plasenta dan penambahan volume darah ibu. Sebagian dari peningkatan ini dapat dipenuhi oleh simpanan zat besi dan peningkatan adaptif persentase zat besi yang diserap.(Dewi,2019) Tetapi bila simpanan zat besi rendah atau tidak ada sama sekali dan zat besi yang diserap dari makanan sangat sedikit maka, diperlukan suplemen preparat besi. (Depkes RI, 2007)

Faktor usia kehamilan ibu juga memengaruhi kadar hemogobin ibu. Menurut Yulin (2018), anemia dapat terjadi sebagai akibat perubahan sistem hematologi dalam masa kehamilan. Pada ibu hamil dengan anemia biasanya mengeluh merasa lemah, pucat, dan mudah pingsan sementara tensi masih dalam batas normal, perlu dicurigai anemia defisiensi. Secara klinik dapat dilihat tubuh yang malnutrisi, pucat (Yulin, 2018).

Anjuran perlu disampaikan terutama bagi yang pertama kali hamil, atau kehamillanya sejak pertama sudah mempunyai masalah, sehingga memerlukan perhatian khusus. Peristiwa kehamilan dapat diterima dalam dua bentuk yaitu kehamilan yang diharapkan dan diterima dengan baik atau perasaan takut hamil dan menghadapi persalinan. Kedua keluhan ini dapat menimbulkan berbagai bentuk gejala klinis sehingga memerlukan anjuran untuk dapat mengatasinya dan mulai beradaptasi terhadap kehamilan. Nasihat untuk ibu hamil mencakup anjuran yang berkaitan dengan pencegahan psikologis dan rasa takut menghadapi kehamilan dan persalinan.

Berdasarkan hasil penelitian peneliti berasumsi bahwa pemberian Jus Buat Bit terhadap kenaikan kadar hemoglobin pada ibu hamil banyak faktor yang dapat menyebabkan timbulnya anemia defisiensi besi, antara lain kurangnya asupan zat besi dan protein dari makanan, adanya gangguan absorpsi di usus, perdarahan akut maupun kronis, dan meningkatnya kebutuhan zat besi seperti pada wanita hamil, masa pertumbuhan dan masa penyembuhan dari penyakit. Anemia merupakan masalah kesehatan masyarakat terbesar di dunia terutama bagi kelompok wanita usia reproduksi (WUS).(Astriana,2017)

\section{Analisis Bivariat \\ Pengaruh Jus buah Bit Terhadap kenaikan Kadar Hemoglobin Pada Ibu Hamil Dengan Anemia Di UPTD Puskesmas Sudimoro Tanggamus Lampung Tahun 2019}

Berdasarkan tabel 2 diketahui bahwa nilai rata-rata (mean) Kadar Hemoglobin pada responden sebelum diberikan jus buah bit adalah 9.835 dengan standar deviasi .5689. Sedangkan nilai rata-rata (mean) Kadar Hemoglobin pada responden sesudah diberikanjus buah bit adalah 11.771 dengan standar deviasi 1.2164 dan selisih rerata 1.9353. Hasil uji statistik dengan uji $t$ dependen sample test diperoleh nilai $p$-value $=$ 0,000 ( $p$-value $<a=0,05$ ), hasil ini menunjukkan bahwa ada Pengaruh pemberian Jus buah Bit Terhadap peningkatanKadar Hemoglobin Pada Ibu Hamil.

Berdasarkan penelitian Anggraini(2019) yang telah dilakukan di wilayah kerja puskesmas Pekanbaru kota, didapatkan hasil uji statistik dengan menggunakan uji $t$ independent diperoleh $\mathrm{p}$ $(0,000)<a(0,05)$. Hal ini dikatakan terdapat perbedaan yang signifikan antara mean kadar hemoglobin ibu hamil dengan anemia pada kelompok eksperimen dan kelompok kontrol sesudah diberikan jus buah bit sehingga dapat disimpulkan bahwa pemberian jus buah bit efektif terhadap kadar hemoglobin ibu hamil dengan anemia.

Anemia merupakan salah satu kelainan darah yang umum terjadi ketika kadar sel darah merah dalam tubuh menjadi terlalu rendah. Hal ini dapat menyebabkan masalah kesehaan karena sel darah merah mengandung hemoglobin, yang membawa oksigen ke jaringan tubuh. Anemia dapat menyebabkan berbagai komplikasi, termasuk kelelahan dan stress pada organ tubuh. Memiliki 
kadar sel darah merah yang normal dan mencegah anemia membutuhkan kerjasama antara ginjal, sumsum tulang, dan nutrisi dalam tubuh. Jika ginjal atau sumsum tulang tidak berfungsi, atau tubuh kurang gizi, maka jumlah sel darah merah dan gunsi normal mungkin sulit untuk dipertahankan (Proverawati, 2011).

Anemia menggambarkan kondisi dimana jumlah sel darah merah dalam darah rendah. Darah terdiri dari dua bagian, sebuah bagian cair yang disebut plasma dan sebagian yang padat disebut sel darah. (Firain,2018).Bagian seluler berisi beberapa jenis sel yang berbeda. Salah satu tipe yang paling penting dan jenis sel yang paling banyak adalah sel darah merah. Anemia dapat diwariskan secara genetik. Gangguan herediter dapat mempersingkat masa pakai sel darah merah dan menyebabkan anemia. Gangguan herediter juga dapat menyebabkan anemia dengan mersuka produksi hemoglobin. Tergantung pada derajat kelainan genetik, anemia yang diwariskan dapat menyebabkan anemia ringan, sedang, atau berat. (Proverawati, 2011)

Tubuh mengalami perubahan signifikan saat hamil.Jumlah darah dalam tubuh meningkat sekitar $20-30 \%$, sehingga memerlukan peningkatan kebutuhan pasokan besi dan vitamin untuk membuat hemoglobin.Ketika hamil, tubuh membuat lebih banyak darah untuk berbagi dengan bayinya.Tubuh mungkin membutuhkan darah hingga $30 \%$ lebih banyak dari pada ketika tidak hamil. Jika tubuh tidak memiliki cukup zat besi , tubuh tidak dapat membuat sel-sel darah merah yang dibutuhkan untuk membuat darah ekstra. Hemoglobin adalah protein dalam sel darah merah yang membawa oksigen ke sel-sel dalam tubuh. (Proverawati, 2011).

Beberapa bentuk umum dari anemia yang paling mudah dicegah dengan makan makanan yang sehat dan membatasi penggunaan alkohol. (Sianturi,2018)Semua jenis anemia sebaiknya dihindari dengan memeriksaan diri ke dokter secara teratur dan ketika masalah itu timbul. Darah para lanjut usia secara rutin diperintahkan oleh dokter untuk selalu dikontrol, bahkan jika tidak ada gejala, sehingga dapat terdeteksi adanya anemia dan meminta dokter untuk mencari penyebab yang mendasari (Proverawati, 2011).

Nutrisi yang baik adalah cara terbaik untuk mencegah terjadinya anemia jika sedang hamil atau mencoba menjadi hamil.(Siswosuharjo,2011) Makan makanan yang tinggi kandungan zat besi (seperti sayuran berdaun hijau, daging merah, sereal, telur, dan kacang tanah) dapat membantu memastikan bahwa tubuh menjaga pasokan besi yang diperlukan untuk berfungsi dengan baik. Pemberian vitamin untuk memastikan bahwa tubuh memiliki cukup asam besi dan folat. Pastikan tubuh mendapatkan setidaknya $27 \mathrm{mg}$ zat besi setiap hari(Palupi,2018). Jika mengalami anemia selama kehamilan, biasanya dapat diobati dengan mengambil suplemen zat besi. Pastikan bahwa wanita hamil dicek pada kunjungan pertama kehamilan untuk pemeriksaan anemia. (Proverawati, 2011).

Buah Bit memiliki banyak manfaat bagi kesehatan maupun pengobatan, kandungan betasianin pada buah bit bermanfaat sebagai anti kanker, karena zat tersebut dapat menghancurkan sel tumor dan kanker. Buah Bit juga bermanfaat mencegah penyakit stroke, menurunkan kolesterol, mencegah penyakit jantung, memperkuat daya tahan tubuh, mengeluarkan racun dari dalam tubuh. Mengobati infeksi dan radang, sebagai penghasil energi bagi tubuh serta meningkatkan sistem kekebalan tubuh. Buah Bit merupakan salah satu buah yang memiliki nutrisi yang kompit dan sangat baik untuk di konsumsi secara rutin (Suryandari, 2015).

Mengatasi gangguan hati dan kantung empedu, menghancurkan sel tumor dan sel kanker, memperkuat fungsi darah dan mengatasi anemia, memproduksi sel-sel darah, menurunkan kadar kolesterol jahat, membersihkan dan menetralkan racun di dalam tubuh, memperkuat sistem peredaran darah dan sistem kekebalan, melawan infeksi dan radang, mengatasi masalah batu ginjal dan memberi tenaga dan menyeimbangkan tubuh (Savitri,2016).

Bit merupakan sumber Vitamin C, selain itu Bit juga banyak mengandung Vitamin $B$ dan Vitamin A sehingga baik untuk kesehatan tubuh. Oleh karena itu, Bit pun dianjurkan di konsumsi dalam jumlah yang banyak bagi penderita darah rendah (Sunarjono, 2004). Anemia pada ibu hamil ini dapat dicegah dengan mengkonsumsi zat besi minimal 90 tablet $\mathrm{Fe}$ berdasarkan program pemerintah dan dengan mengkonsumsi buah bit. Buah bit ((Beta Vulgaris) merupakan tanaman yang tumbuh di dalam tanah sejenis umbi-umbian yang berwarna merah keunguan(Utaminimgtyas,2017)

Anemia bisa diakibatkan oleh kehilangan darah, penurunan produksi sel darah merah, peningkatan destruksi sel darah merah, atau kombinasi ketiga penyebab ini.(Oehadian,2012) Alternatif pengobatan anemia dan pencegahan bisa dilakukan dengan mengonsumi buah bit. Bit mengandung vitamin, mineral, asam amino, kalori, antioksidan, anti karsinogenik, silica, juga mengandung pigmen betain yang dikenal dengan 


\section{JKM (Jurnal Kebidanan Malahayati),Vol 7,No.2.April 2021, \\ ISSN (Print) 2476-8944 ISSN (Online) 2579-762X, Hal 257-264}

trimetil glisin, glisin betain, lisin, dan oksineurin yang berfungsi sebagai pendonor metil dan meningkatkan metionin serum, kadar transmetilasi, remetilasi homosistein dan oksidasi metionin pada orang sehat(Sabila). Hewan yang diinjeksi dengan betain menunjukkan peningkatan SAM-donor metil pada sintesis protein, keratin, fosfolipid, hormone, poliamin, karnitin, adrenalin dan metilasi DNA, pada sel darah merah.(Putri,2016). Terdapat peningkatan yang bermakna terhadap nilai Indek Eritrosit setelah mengonsumsi buah bit. Konsumsi buah bit berpengaruh terhadap peningkatan nilai indek eritrosit remaja putri dengan anemia.(Ikawati,2018)

Berdasarkan hasil penelitian peneliti berasumsi bahwa ada perbedaan kenaikan kadar hemoglobin pada ibu hamil sebelum dan sesudah mengkonsumsi jus buat bit. Ibu hamil yang tidak mengalami kenaikan kadar hemoglobin disebabkan karena asupan nutrisi yang tidak cukup, kurang istirahat, bertambahnya zat gizi yang hilang, dan meningkatnya kebutuhan nutrisi ibu selama masa hamil dan juga disebabkan karena faktor usia. Sedangkan ibu hamil yang mengalami kenaikan kadar hemoglobin disebabkan karena ibu sering mengkonsumsi makanan yang mengandung nilai gizi bermutu tinggi meskipun tidak berarti makanan yang mahal harganya, ibu hamil teratur mengkonsumsi makanan yang mengandung protein, zat besi, dan minum cukup cairan (menu seimbang). Selain itu faktor tingginya angka kenaikan kadar hemoglobin disebabkan oleh cukupnya waktu untuk beristirahat, kesadaran terhadap asupan gizi yang dikonsumsi sehingga dapat mempercepat kenaikan kadar hemoglobin.

\section{SIMPULAN}

Dari hasil penelitian dan pembahasan pada bab sebelumnya, maka dapat disimpulkan hal-hal sebagai berikut, kadar hemoglobin sebelum pemberian Jus buah Bit 9.835, kadar hemoglobin sesudah pemberian Jus buah Bit 11.771, Ada pengaruh pemberian Jus buah bit terhadap peningkatan kadar hemoglobin pada ibu hamil dengan $p$-value $=0,000<\alpha=0,005$.

\section{SARAN}

Saran bagi ibu hamil dapat mengkonsumsi jus buah bit secara rutin guna pencegahan terjadinya anemia serta mengkonsumsi makanan yang mengandung vitamin $\mathrm{C}$.

\section{DAFTAR PUSTAKA}

Anggraini, D. D., \& Saragita, N. (2019). Pengaruh Pemberian Jus Buah Bit Terhadap Kenaikan
Kadar Hb Pada Ibu Hamil Trimester III. Jurnal Darul Azhar Vol. 8 No, 1.

Anurogo, D. (2016). The Art of Medicine. Gramedia Pustaka Utama.

Astriana, W. (2017). Kejadian anemia pada ibu hamil ditinjau dari paritas dan usia. Aisyah: Jurnal IImu Kesehatan, 2(2), 217394.

Astuti, R. Y., \& Ertiana, D. (2018). Anemia dalam Kehamilan. Pustaka Abadi.

Desi, W. (2018). Pengaruh Pemberian Tablet Zink dan Besi terhadap Kadar Hemoglobin dan Feritin pada Ibu Hamil Anemia Defisiensi Besi (Doctoral dissertation, Universitas Andalas).

Dewi, S. R. (2019). APLIKASI SMS REMINDER DENGAN EDUKASI UNTUK MENGATASI EFISIEN PENGETAHUAN PADA KEPATUHAN IBU HAMIL DALAM MENINGKATKAN KONSUMSI TABLET $B E S I$ (Doctoral dissertation, Tugas Akhir, Universitas Muhammadiyah Magelang).

Dinas Kesehatan Kabupaten Tanggamus, 2017.Profil Dinas Kesehatan Tanggamus

Firani, N. K. (2018). Mengenali Sel-Sel Darah dan Kelainan Darah. Universitas Brawijaya Press.

Ikawati, K. (2018). PENGARUHÂ BUAH BIT (BETA VULGARIS) TERHADAPÂ INDEK ERITROSIT PADA REMAJA PUTRI DENGAN ANEMIA. Journal of Nursing and Public Health, 6(2), 60-66.

Kementerian Kesehata Republik Indonesia,Kemenkes RI. 2017

Manuaba, I. B. G. (2009). IImu kebidanan, penyakit kandungan \& keluarga berencana untuk pendidikan bidan. Egc.

Oehadian, A. (2012). Pendekatan klinis dan diagnosis anemia. Continuing Medical Education, 39(6), 407-412.

Palupi, F. H., \& Anggraini, Y. (2018). PEMERIKSAAN HEMOGLOBIN TEST STRIPGUNA MENGIDENTIFIKASI ANEMIA PADA IBU HAMIL DI KLINIK MITRA HUSADAKARANGANYAR. Maternal, 13(1).

Proverawati, Atikah. 2011 Anemia dan anemia kehamilan.Yogyakarta : Nuha Medika

Putri, M. C. (2016). Efek Antianemia Buah Bit (Beta vulgaris L.). Jurnal Majority, 5(4), 96-100.

Rimawati, E., Kusumawati, E., Gamelia, E., \& Nugraheni, S. A. (2018). Intervensi Suplemen Makanan Untuk Meningkatkan Kadar Hemoglobin Pada Ibu Hamil. Jurnal IImu Kesehatan Masyarakat, 9(3), 161-170.

Riskesdas, 2018. Hasil Utama Riskesdas 2018. Kementrian Kesehatan Badan Penelitian 
Dan Pengembangan Kesehatan. Indonesia; kemenkesri

Sabilla, S. Edukasi Manfaat Buah Bit bagi Penderita Anemia.

Savitri, A. (2016). Tanaman Ajaib! Basi Penyakit dengan TOGA (Tanaman Obat Keluarga). Bibit Publisher.

Setyiyaningsih, S., Widayati, W., \& Kristiningrum, W. (2020). KEEFEKTIFAN JUS BUAH BIT DAN LEMON DALAM KENAIKAN KADAR HB PADA IBU HAMIL. Jurnal Kebidanan Malahayati, 6(1), 71-76.

SIANTURI, D. (2018). FAKTOR YANG BERHUBUNGAN DENGAN ASUPAN NUTRISI TERHADAP KEJADIAN ANEMIA PADA IBU HAMIL DI KLINIK PRATAMA IRMA MEDAN TAHUN 2018 (Doctoral dissertation, DORMIAN SIANTURI).

Siswosuharjo, S., Chakrawati, F., \& Sos, S. (2011).

Panduan super lengkap hamil sehat. PT Niaga Swadaya.

Sunarjono, H. H. (2004). Bertanam 36 jenis sayur. Penebar Swadaya Grup.

Suryandari, A. E., \& Happinasari, O. (2015). Perbandingan Kenaikan Kadar Hb Pada Ibu
Hamil Yang diberi Fe Dengan Fe dan Buah Bit di Wilayah Kerja Puskesmas Purwokerto Selatan. Jurnal Kebidanan, 7(01).

Suryandari, A. E., \& Happinasari, O. (2014). Perbandingan kenaikan kadar $\mathrm{Hb}$ pada ibu hamil yang diberi $\mathrm{Fe}$ dengan $\mathrm{Fe}$ dan buah bit. Bhamada: Jurnal IImu dan Teknologi Kesehatan (E-Journal), 5(2), 9-9.

Susiloningtyas, I. (2021). Pemberian zat besi (Fe) dalam Kehamilan. Majalah IImiah Sultan Agung, 50(128), 73-99.

Utaminingtyas, F. (2017). Manfaat Buah Bit (Beta vulgaris) Terhadap Peningkatan Kadar Haemoglobin $(\mathrm{Hb})$ Ibu Hamil. Jurnal IImiah Kesehatan Ar-Rum Salatiga, 2(1), 41-45.

World Health Organization. (2015). World health statistics 2015. World Health Organization.

Yulin Dwiya Ramadhani, N. (2018). ANALISIS FAKTOR-FAKTOR YANG BERHUBUNGAN DENGAN KEJADIAN ANEMIA PADA IBU HAMIL TRIMESTER III DI PUSKESMAS KALIJUDAN SURABAYA (Doctoral dissertation, Universitas Airlangga). 